\title{
TRANSFORMATION OF EDUCATION AS THE PRECONDITION OF THE ESTABLISHMENT OF EPISCOPAL SEE IN ALEXANDRIA IN SECOND AND THIRD CENTURY ${ }^{* *}$
}

The most natural environment for a religious experience, kerygma, and doctrine of primitive Christians was undoubtedly grounded in the Jewish synagogue, Beth Knesset, which has been a central communal institution of Judaism. In fact, it had been the native educational milieu for Jesus himself, who must have been enrolled in a synagogal school in his childhood and later used it for preaching in his adult life. Even though until $70 \mathrm{CE}$ Jerusalem Temple was the center of the Jewish cult, the synagogue clearly had its own particular function, serving as a local meetinghouse for study and, also, prayer. In effect, its administrators were none other than teachers, rabbis. When the Jerusalem Temple was destroyed, the synagogue became its surrogate. Consequently much of the liturgy and instruction of rabbinic Judaism and newly emerging Judeo-Christianity - even the times of statutory prayer and the number of services held on holidays and festivals - was framed to correspond with the rituals and rhythms of the defunct Temple cult ${ }^{1}$.

It is in the light of Jewish school (synagogue) that the emergence of the institutionalized Christian communities in Alexandria needs to be looked at, since being perhaps more radical in his theological and ethical demands than his contemporaneous Jewish $m i l i e u^{2}$, Jesus Christ and his immediate disci-

* Oleh Kindiy Ph.D. - Professor employed in the Department of Theology at the Faculty of Philosophy and Theology of the Ukrainian Catholic University in Lviv; e-mail: okindiy@ucu.edu.ua.

${ }^{* *}$ Parts of this presentation is based on my doctoral dissertation, Christos Didascalos. The Christology of Clement of Alexandria, Saarbrücken 2008.

${ }^{1}$ His first volume on early Christianity Jean Daniélou dedicated to Judeo-Christianity, cf. idem, A History of Early Christian Doctrine before the Council of Nicaea, vol. 1: The Theology of Jewish Christianity, transl. and ed. by J.A. Baker - D. Smith, London-Philadelphia 19732; see also D.R. Schwartz, Studies in the Jewish Background of Christianity, Wissenschaftliche Untersuchungen zum Neuen Testament 60, Tübingen 1992; O. Skarsaune, In the Shadow of the Temple: Jewish Influences on Early Christianity, Downers Grove 2002.

${ }^{2}$ Cf. G. Theissen, The Wandering Radicals. Light Shed by the Sociology of Literature on the Early Transmission of Jesus Sayings, in: Social Reality and the Early Christians: Theology, Ethics and the World of the New Testament, translated by M. Kohl, Minneapolis 1992, 33-59; idem, The 
ples were Palestinian rabbis (teachers), for whom their rabbinic vocation was of the immediate and decisive importance ${ }^{3}$. Consequently, the fact that they were teachers had a crucial impact on early Christianity to a degree that early Christians had to become teachers in order to transmit the teaching of Christ (cf. Mt 28:19; Mk 16:15; Lk 24:47; Col 1:23).

A transition from the Jewish synagogue to the early Christian church/ school was never a straightforward process. At the same time, the difference between school and church in early Christianity has never been clearly contoured ${ }^{4}$. Today it is agreed that under Hellenistic influence the institution of the early Christian school and thus the status of teacher took on an entirely new form. Adolf von Harnack looked at the process through the prism of his thesis of the Hellenization of primitive Christianity, which, according to his thesis, by the end of the third century completely lost its genuinely „charismatic" character and succumbed to an institutionalized schooling formed in accordance with the customs, methods, and structure of Hellenistic education ${ }^{5}$. Karl H. Rengstorf and recently Alfred F. Zimmermann examined the striking discontinuity between the first century Christian school that was still part of Jewish synagogal infrastructure and the second century Christian schools that confidently and actively embraced Hellenistically fostered instruction (Tertullian [c. 150-220] and Tatian [c. 120-180] being false exceptions, since undoubtedly they were also legitimate heirs to Greco-Roman upbringing) ${ }^{6}$. K.H. Rengstorf and A.F. Zimmermann concluded that the distance and indeed the fracture between the two communities, Jewish and Christian, originally took place not so much in the realm of theological discourse as on the level of educational organization and technique ${ }^{7}$. However, Werner Jaeger and Hans

Religion of the Earliest Churches. Creating a Symbolic World, transl. by J. Bowden, Minneapolis 1999, 27-40 and 96-99.

${ }^{3}$ On the connection between Christ the teacher and early Christian theology, cf. F. Normann, Christos Didaskalos: die Vorstellung von Christus als Lehrer in der christlichen Literatur des ersten und zweiten Jahrhunderts, Münsterische Beiträge zur Theologie 32, Münster 1966; R. Riesner, Jesus als Lehrer: eine Untersuchung zum Ursprung der Evangelien-Überlieferung, Wissenschaftliche Untersuchungen zum Neuen Testament 2. Reihe 7, Tübingen 1984²; U. Neymeyr, Die christlichen Lehrer im zweiten Jahrhundert: ihre Lehrtätigkeit, ihr Selbstverständnis und ihre Geschichte, Supplements to „Vigiliae Christianae” 4, Leiden - New York 1989.

${ }^{4}$ Cf. A. van den Hoek, How Alexandrian was Clement of Alexandria? Reflections on Clement and his Alexandrian Background, „Heythrop Journal” 31 (1990), nr 1, p. 182. Cf. also A. von Harnack, Geschichte der altchristlichen Literatur bis Eusebius, Bd. 2: Die Chronologie der Literatur von Irenäus bis Eusebius, Leipzig 1904, p. 3.

${ }^{5}$ Cf. A. von Harnack, Die Lehre der zwölf Apostel, nebst Untersuchungen zur ältesten Geschichte der Kirchenverfassung des Kirchenrechts, TU 2/2, Leipzig 1884; idem, Die Mission und Ausbreitung des Christentums in den ersten drei Jahrhunderten, 2. Bde, Leipzig 19244.

${ }^{6}$ On Tertullian and Tatian, cf. E.F. Osborn, Tertullian: The First Theologian of the West, Cambridge 1977; G.F. Hawthorne, Tatian and His Discourse to the Greeks, HTR 57 (1964) 161-188.

${ }^{7}$ Cf. K.H. Rengstorf, $\delta ı \delta \alpha \sigma \kappa \omega$, TWNT II 138-168; A.F. Zimmermann, Die urchristlichen 
F. von Campenhausen demonstrated that there actually was a historical continuity between the first and following centuries of Christian schools, despite the drastic change that came into effect after early Christians opened the doors of their schools to non-Christians. As arguments in defense of this thesis, they demonstrated, first of all, that Christian schools of the second, third and fourth centuries remained part of the communal undertaking; and, second of all, the revelatory texts, scriptural learning and interpretation continuously played a central role for both the old and new churches, even though the methods and approaches to Christian education of the later periods were borrowed from the larger socially established and philosophically ingrained paradigm of Hellenistic paideia ${ }^{8}$. Evangelically justified openness of early Christian schools to non-Jews and non-Christians attracted a significant number of new members, since these schools were easily accessible and in most cases free of charge and sponsored by the entire community, in contrast to Greco-Roman schools, which were open only to the élite, which thereby was maintaining and protecting its upper social status and requiring considerable fees for the complete course of studies.

The first three centuries of the formation of Christian school and its transition from a synagogal to Hellenistic educational forms brought forth several different types of early Christian teachers, who responded to different „talents of the Spirit". They have been tentatively classified as prophets, itinerary and professional teachers, ministers and catechists, each of whom carried out their specific vocations even though their functions could easily overlap. Prophets received and conceived the main guidelines of divine revelation. Itinerary teachers charged by eschatological vigor traveled from town to town and preached the revelation, kerygma. Learned teachers explored, applied, and handed down the guidelines and content of the revelation and kerygma in a more structured and comprehensive way. At last, ministers and catechists made the utmost use of the kerygma for ecclesiastical structuralization and growth ${ }^{9}$.

Classical paideia was the intellectual vehicle that by its constant dynamic evolution stood at the very center of the social structure, organization, and identity of the second and third century Alexandria. Harry Y. Gamble and William V. Harris have shown, that ,granting regional and temporal variations, throughout the entire period of classical Greek, Hellenistic, and Roman imperial civilization, the extent of literacy was about 10 percent and never exceeded 15 to 20 percent of the population as a whole" ${ }^{10}$. There are always exceptions

Lehrer. Studien zum Tradentenkreis der, ,didaskaloi” im frühen Urchristentum, Wissenschaftliche Untersuchungen zum Neuen Testament 2. Reihe 12, Tübingen 1984, esp. p. $218 \mathrm{ff}$.

${ }^{8}$ Cf. W. Jaeger, Early Christianity and Greek Paideia, Cambridge Mass. 1961; H.F. von Campenhausen, Kirchliches Amt und geistliche Vollmacht in den ersten drei Jahrhunderten, Beiträge zur Historischen Theologie 14, Tübingen 1963², esp. p. 210-233.

${ }^{9}$ Cf. Neymeyr, Die christlichen Lehrer im zweiten Jahrhundert, pp. 1-2.

${ }^{10}$ H.Y. Gamble, Books and Readers in the Early Church. A History of Early Christian Texts, 
to the rule. One exception is the higher rank of the literate population in the reformed post-Ezrian Palestine, higher than in the average Greco-Roman region due to the social structure and identity preserving/shaping nature of the synagogal institution that provided means for schooling its young and adult members: most men and some women must have been able to at least read Torah ${ }^{11}$. Another exception is the replication of the literary infrastructure throughout the Jewish Diaspora outside Palestine. Therefore, special attention has to be paid to second-century Egypt and more specifically Alexandria as it remained the Greco-Roman educational and cultural capital of the Mediterranean basin, abd also perhaps the largest and wealthiest Jewish Diaspora of the period.

Colin H. Roberts pointed out that there is simply not much concrete data for the early church in Alexandria before the installment of the bishop Demetrius (d. 232) in and around the year 189. It is generally agreed today that the list of successive bishops from the apostle Mark to Demetrius is simply Eusebius' (c. 264-340) invention to fill in the gap between apostolic origins up to Demetrius ${ }^{12}$. Yet even though there is not much information about the development of the Christian institutional church, there is a broad discussion of the significant impact of classical paideia and Jewish education on the formation of early Christian communities and its generous and ample Alexandrian illustration in Clement's (c. 150-c. 212) and Origen's (c. 185-254) theological interpretations ${ }^{13}$.

New Haven 1995, 4; W.V. Harris, Ancient Literacy, Cambridge Mass. 1989, passim; cf. also R. Thomas, Oral Tradition and Written Record in Classical Athens, Cambridge Studies in Oral and Literate Culture 18, Cambridge 1989, 15-34.

${ }^{11}$ Cf. Gamble, Books and Readers in the Early Church, p. 7 and nn. 21, 22 and 23; M. Hengel, Judaism and Hellenism: Studies in their Encounter in Palestine during the Early Hellenistic Period, vol. 2: Notes and Bibliography, transl. by J. Bowden, London 1974², 78-73; S. Safrai, Education and the Study of Torah, in: The Jewish People in the First Century. Historical Geography, Political History, Social, Cultural and Religious Life and Institutions, ed. by S. Safrai - M. Stern, vol. 2, Compendia Rerum Iudaicorum ad Novum Testamentum I/2, Assen 1976, 945-970; see also Iosephus, Contra Apionem II 204; idem, Antiquitates Iudaicae IV 211; Testamentum Levi XIII 2; Philo, Ad Gaium 115.

${ }^{12}$ Cf. W. Telfer, Episcopal Succession in Egypt, „Journal of Egyptian History” 3 (1952) 1-13.

${ }^{13}$ On the conception of Clement's didaskalos, cf. E. Fascher, Jesus der Lehrer, ThL 79 (1954) 326-342; idem, Der Logos-Christus als göttlicher Lehrer bei Clemens von Alexandrien, in: Studien zum Neuen Testament und zur Patristik. Erich Klostermann zum 90. Geburtstag dargebracht, hrsg. von der Kommission für spätantike Religionsgeschichte, TU 77, Berlin 1961, 193-207; A. Knauber, Katechetenschule oder Schulkatechumenat? Um die rechte Deutung des „Unternehmens” der ersten grossen Alexandriener, „Trierer Theologische Zeitschrift” 60 (1951) 243-266; idem, Ein frühchristliches Handbuch katechumenaler Glaubensinitiation: der Paidogogos des Clemens von Alexandrien, MThZ 23 (1972) 311-334; idem, Der „Didaskalos” des Clemens von Alexandrien, StPatr 16 (1985) 175-185; Normann, Christos Didaskalos, pp. 153-177; A.K. Koffas, Die SophiaLehre bei Klemens von Alexandrien: eine pädagogisch-anthropologische Untersuchung, Eruditio 14, Frankfurt am Main 1982; J.L. Kovacs, Divine Pedagogy and the Gnostic Teacher according to Clement of Alexandria, JECS 9 (2001) 3-25; see also G. Kretschmar, Jesus Christus in der 
For example, Adolf Knauber demonstrated that in the second-century Alexandria not only was there a clear understanding of a need for a school for catechumens but also that there was already intact a multilateral program, rules, and rituals that accompanied the program. To support his thesis he quoted Clement of Alexandria's book Paedagogus:

„But we need a Teacher of the exposition of those sacred words, to whom we must direct our steps. And now, in truth, it is time for me to cease from my pedagogy, and for you to listen to the Teacher. And He, receiving you who have been trained up in excellent discipline, will teach you the Scriptures ( $\tau \grave{\alpha} \lambda{ }^{\prime} \gamma(\alpha)$. The church is here for the good, and the Bridegroom is the only Teacher, the good will of the good Father, the true wisdom, the sanctuary of knowledge" 14 .

The majority of scholars emphasize Clement's ecclesiastical inclination in this passage since the proper teaching of the sacred words, according to Clement, ought to take place within the space of the church ${ }^{15}$. A. van den Hoek pointed out here that Eduard Schwarz even amended the phrase in MS $\mathrm{P}^{16}$

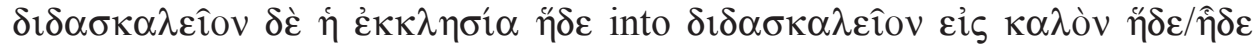
which slightly changes the meaning by turning the church into the school. This emendation, however, according to A. van den Hoek, who agrees with

Theologie des Klemens von Alexandrien (Doctoral Dissertation [Maschinenschrift]), Heidelberg 1950; M. Mees, Die frühe Christengemeinde von Alexandrien und die Theologie des Klemens von Alexandrien, „Latomus” 50 (1984) 114-126; B.A. Pearson, Earliest Christianity in Egypt: Some Observations, in: The Roots of Egyptian Christianity, ed. by B.A. Pearson - J. E. Goering, Studies in Antiquity and Christianity, Philadelphia 1986, 132-160; Neymeyr, Die christlichen Lehrer im zweiten Jahrhundert, pp. 45-95.

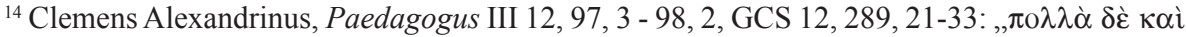

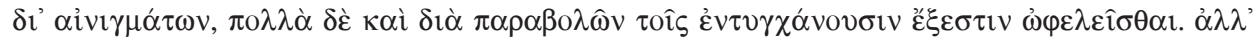

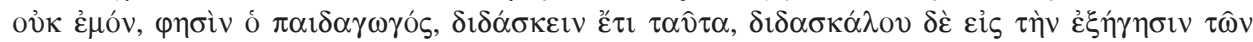

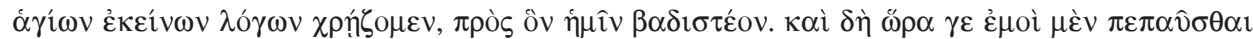

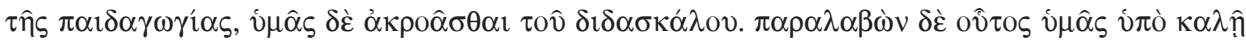

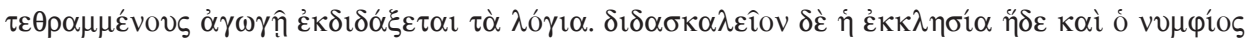

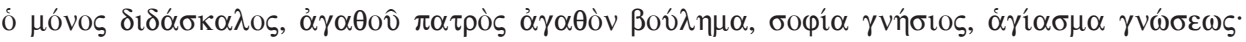

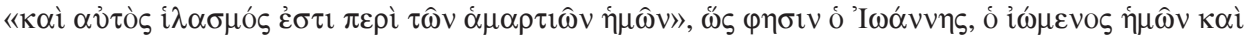

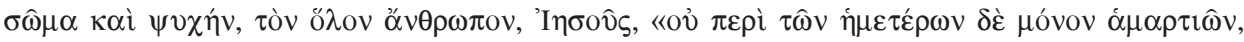

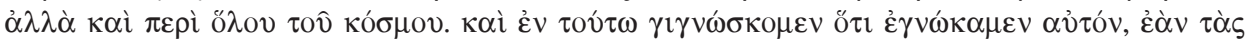
$\varepsilon \dot{\varepsilon} \tau \tau \lambda \lambda \dot{\alpha} \varsigma \alpha \hat{\tau} \tau 0 \hat{~} \tau \eta \rho \hat{\omega} \mu \varepsilon v »$ [1John 2:2-3]".

${ }^{15}$ Cf. A. van den Hoek, The 'Catechetical' School of Early Christian Alexandria and Its Philonic Heritage, HTR 90 (1997) 65; Neymeyr, Die christlichen Lehrer im zweiten Jahrhundert, p. 57-58; Knauber, Ein frühchristliches Handbuch katechumenaler Glaubensinitiation, p. 327; idem, Der „Didaskalos” des Clemens von Alexandrien, p. 180-181; Normann, Christos Didaskalos, p. 174; Fascher, Der Logos-Christus als göttlicher Lehrer, p. 206-207.

${ }^{16}$ The Parisian manuscript, Codex Parisinus Graecus 451 (Parchment) - Paris, Bibliothèque Nationale. Cf. n. 17. 
Otto Stählin, is superfluous ${ }^{17}$ since ,from Clement's perspective... a contrast between church and school is nonexistent"18. Even without such textual emendation it is very clear that Clement perceived the process of education within the boundaries of the ecclesial community.

Birger A. Pearson, Albertus F.J. Klijn, and C. Wilfred Griggs, to name just a few contemporary scholars of the earliest Christian Egyptian history, agree with Colin H. Roberts' following opening remarks to his study of Christianity in Egypt that ,the obscurity that veils the early history of the church in Egypt and that does not lift until the beginning of third century constitutes a conspicuous challenge to the historian of primitive Christianity"19. It is widely recognized that the problem does not arise from a lack of evidence, for during the last three centuries hundreds of manuscripts and fragments at large that were written or circulated in the three first centuries of the Christian era have been discovered in Egypt. The evidence that we possess, however, does not specifically speak of the ways Christianity was founded and initially evolved in Egypt. Thus for scholars of early Christianity of this period, it takes much imagination and close reading of the extant literary and archeological evidence to deduce just what kind of communities these early Christian, Judeo-Christian, and Gnostic groups were and how they evolved before the installment of the Alexandrian bishop Demetrius in the late second and beginning of the third centuries, a point, from which on, the evidence is more informative and clear with his episcopacy the domination of the ecclesiastically Catholic community managed to gradually absorb, accommodate, and structure the multitude of separate groups into one recognizable body.

Scholars usually point to at least three plausible explanations of the lack of clear information prior to Demetrius' ecclesiastical enthronement. First, as pointed out by C.W. Griggs, in Lucan Acts of the Apostles Christian diffusion throughout the Mediterranean area was predominantly oriented towards Palestine, Asia Minor, and Europe and tended to focus less attention on the Egyptian vector. In addition, Paul's missionary itinerary and epistolary com-

${ }^{17}$ Cf. Van den Hoek, The 'Catechetical' School of Early Christian Alexandria, p. 65.

${ }^{18}$ Van den Hoek, The 'Catechetical' School of Early Christian Alexandria, p. 71.

${ }^{19}$ C.H. Roberts, Manuscript, Society, and Belief in Early Christian Egypt, London 1979, 1, which just resonates A. von Harnack's intuition expressed in his Die Mission und Ausbreitung des Christentums, Bd. 2: Die Verbreitung, p. 706. C.H. Robert's passage is cited by B.A. Pearson, cf. idem, Earliest Christianity in Egypt, p. 132-159; cf. also in the B.A. Pearson's volume the article A.F.J. Klijn, Jewish Christianity in Egypt, in: The Roots of Egyptian Christianity, p. 161-175. More recent studies on the subject are: C.W. Griggs, Early Egyptian Christianity from its Origins to 451 C.E., Coptic Studies 2, Leiden 19933; R. van den Broek, Studies in Gnosticism and Alexandrian Christianity, NHS 39, Leiden 1996; A. Jakab, Ecclesia alexandrina: évolution sociale et institutionnelle du christianisme alexandrin (II et $I I^{e}$ siècles), Christianismes Anciens 1, Bern 2001; B.A. Pearson, Gnosticism and Christianity in Roman and Coptic Egypt, Studies in Antiquity and Christianity, New York - London 2004. 
munication clearly leaves the Egyptian province out of the view ${ }^{20}$. Second, there is a great deal of verisimility that the Jewish revolts of 115-117 suppressed by Trajan (98-117) and then the ensuing revolt led by Bar Kochba in 130-136 and callously suppressed by Hadrian (117-138) contributed to the fact that the Jewish and with it the first Judeo-Christian population was drastically purged if not entirely eradicated. These events were crucial for the definitive separation of Christians and Jews as well as the strong anti-Jewish elements found in the writings of the second century Christian Egyptian (usually anonymous or pseudonymous) authors ${ }^{21}$. The third plausible although more and more contested proposal is Walter Bauer's thesis that both Jewish and Gentile Christians of Egypt based their theology and worship on syncretistic and gnostic precepts which with the later (ca the end of the second century) arrival of orthodox ecclesiastical leadership was deemed unorthodox, readily dismissed, and their literary legacy physically destroyed ${ }^{22}$.

The first connections we have between earliest Christianity and Egyptian vicinities come from the New Testament writings although they point out only that the connections were there and not much more. The first remark is the Holy Family's escape from Herod's hand into Egypt (Mt 2:13-21). Egypt is mentioned in the New Testament for the second time at the Pentecost (Acts 2), where Egyptians are enumerated along with the other Diaspora Jews who came to Jerusalem for the Feast of Passover and Pentecost and witnessed the descent of the Holy Spirit on the Apostles right after Jesus ascended to Heaven.

Third, again in the Acts (18:24), we read that ,a certain Jew named Apollo, born at Alexandria, an eloquent man, and mighty in the Scriptures, came to Ephesus". Most likely the same Apollo is mentioned also in Acts 19:1; 1Cor $1: 12 ; 3: 5-6 ; 4: 6 ; 16: 12$; Tit $3: 13^{23}$. At the same time, the Coptic church main-

${ }^{20}$ Cf. Griggs, Early Egyptian Christianity, p. 3-12.

${ }^{21}$ The Jewish revolts of 115-117 and the revolt led by Bar Kochba in 130-136 stand in one line with the pogrom of $38 \mathrm{BCE}$ orchestrated by Flaccus, the governor of Alexandria under Agrippa (63$12 \mathrm{BCE}$ ). This may explain the reluctance of the earliest Christian missionaries to go into Egypt, cf. J. Modrzejewski, The Jews of Egypt: From Rameses II to Emperor Hadrian, transl. by R. Comman, Princeton 1995, 227ff; J.J. Collins, Hellenistic Judaism in Recent Scholarship, in: idem, Jewish Cult and Hellenistic Culture. Essays on the Jewish Encounter with Hellenism and Roman Rule, Supplements to the Journal for the Study of Judaism 100, Leiden 2005, 1-20; and in the same volume his Anti-Semitism in Antiquity? The Case of Alexandria, p. 181-201; see also a broader discussion of this and other relevant issues by V. Tcherikover, Hellenistic Civilization and the Jews, transl. by S. Applebaum, Peabody 1989; J.M.G. Barclay, Jews in Mediterranean Diaspora from Alexander to Trajan (323 BCE-117 CE), Edinburgh 1996; E.S. Gruen, Heritage and Hellenism. The Reinvention of Jewish Tradition, Hellenistic Culture and Society 30, Berkeley 1998.

${ }^{22} \mathrm{Cf}$. W. Bauer, Orthodoxy and Heresy in Earliest Christianity, transl. by a team from the Philadelphia Seminar on Christian Origins and ed. by R.A. Kraft - G. Krodel, Mifflintown 1996, 45ff.; for criticism see Roberts, Manuscript, passim; B.A. Pearson, Earliest Christianity in Egypt, p. $132-159$.

${ }^{23}$ Cf. G. Dorival, Les débuts du christianisme à Alexandrie, in: Alexandrie. Une mégapole 
tains a tradition that Mark the Evangelist was the founder of the church of Alexandria and Egypt. The sources that support this tradition, however, originate only with Eusebius' recoding of a local tradition in his Historia Ecclesiastica $^{24}$, in which he had no document beyond the local legends to prove it accurate even if Mark's presence in Alexandria is not an automatically dismissible fact ${ }^{25}$. The evidence we do have is of a less historiographical and more of a theological and apologetic nature and still may serve as a good source for a better understanding of the Christian community that grew prior to and during Clement's career in Alexandria.

Roelof van den Broek, indirectly reflecting a New Testament socio-theological analysis of James D.G. Dunn, who plausibly differentiated four main tendencies of the first and early second century Christianity (Jewish, Hellenistic, Apocalyptic, and Early Catholic) ${ }^{26}$, identified six distinct Christian groups in second century Alexandria ${ }^{27}$. To begin with, some groups demonstrated a particular focus on apocalyptic urgency, as the author of the Epistle of Barnabas indicates. Second, Alexandrian Jewish wisdom theology and the closely associated conservative, i.e., judaizing, type of Christianity of James is reflected in the Gospel of the Hebrews. Similarly the Gospel of the Egyptians most likely originated from the Greek speaking Egyptian Christians. Fourth, the more educated and philosophically oriented Christians who were later called Gnostics - Basilides (c. 85-145), Valentinus (c. 100-160), Theodotus ( $2^{\text {nd }}$ century) - authored such treatises as the Authoritative Teaching or the Gospel of Truth $^{28}$. R. van den Broek singled out also the Marcionites as a separate faction. Marcionites may have had close ties with the previous group since they have been also called Gnostics who rejected the Hebrew Scriptures altogether. And finally, people like Clement and his teacher Pantaenus (d. c. 216) most likely belonged to the group that preceded the formation of a Catholic, ecclesiastically oriented, congregation that resembled a similar process of structuring as the church of Irenaeus (c. 140-202) in Lyons.

cosmopolite. Actes du gime Colloque de la Villa Kérylos (Beaulieu-sur-Mer, 2-3 octobre 1998), éd. J. Leclant, Cahiers de la Villa Kérylos 9, Paris 1999, 157-174, esp. p. 160-62.

${ }^{24}$ Cf. Eusebius Caesariensis, HE II 16, 1. SCh 31, 71.

${ }^{25}$ Cf. Pearson, Gnosticism and Christianity, p. 12.

${ }^{26}$ Cf. J.D.G. Dunn, Unity and Diversity in the New Testament: An Inquiry into the Character of Earliest Christianity, Harrisburg 199722, 235-366.

${ }^{27}$ Cf. Van den Broek, Studies in Gnosticism, p. 181-196.

${ }^{28}$ Cf. Authenticos Logos, NHC VI 3 22,1 - 35,24, introd. and transl. by H.W. Attridge G.W. MacRae: Authoritative Teaching, in: The Nag Hammadi Library in English, transl. and introd. by members of the Coptic Gnostic Library Project of the Institute for Antiquity and Christianity, ed. J.M. Robinson, San Francisco 199033, 38-51; Evangelium Veritatis, NHC I 3, 16,31 - 43,24, introd. and transl. by G.W. MacRae - D.M. Parrott: Gospel of Truth, in: The Nag Hammadi Library in English, p. 304-310, Polish transl. and commentary W. Myszor: Ewangelia prawdy, PSP 20, 143-192. 
In the Acts of Apostles, Apollo indeed must have been a rabbi in Alexandria or a higher rank Jew ,eloquent in Scriptures”, which indicates that there was an openness to, and reception of, a new interpretation of Hebrew Scriptures through the lenses of the Christian Gospel. The second factor is the educational infrastructure Christians inherited from such Jewish philosophers and thinkers as Aristeas ( $2^{\text {nd }}$ century BCE), Aristobulus ( $\dagger$ c. 160$)$, and Philo of Alexandria (c. $10 \mathrm{BCE}$ - $40 \mathrm{CE}$ ). David Dawson pointed out that these philosophers long ago launched in Alexandria a careful and painstaking subordination of the Greek classical tradition to the Mosaic law ${ }^{29}$. This process could imply that they reflected and actively engaged in the integration of the Jewish education into the larger Greco-Roman paideia. Their curriculum was designed to allow the élite children of Jewish families to be able to enter more easily into the larger society that surrounded them. To a lesser degree, it may have also been targeted to those of Greek, Roman, or other ethnic origin who were interested and willing to join the Jewish group. Membership and participation in the Jewish community did not put up barriers for communication with other communities, even if that communication was polemically flavored. On the contrary, the Jewish and Greco-Roman curricula established themselves in the framework of the same language of literature, philosophy, economy, and political science (cf. below Table 1).

The third factor based on the two preceding ones and probably most decisive for Judeo-Christians in not only an Egyptian milieu, was their openness to, and invitation of, the members of non-Jewish, viz., Greek, Roman, Egyptian (Coptic) and other groups, among which we can enlist Clement, for whom entrance into such congregation did not seem (at least as reflected in his writings) to be difficult at all. Only in the case of Origen do we see an internal tension between a freelance teacher and the ecclesiastical authority. On the contrary, Christians in Alexandria welcomed Clement's and Origen's pedagogical and instructive skills. Even if we accept the suggestion that Clement came from an old Roman aristocratic and therefore most likely financially independent family and did not need to collect salary for his lectures, he and teachers like him still had a guaranteed support from the congregation in which they worked, since the Jewish synagogal structure that included the Beth Sepher (פס חיב), House of Book, and Beth Talmud (חיב דמלח), House of Learning, was on the budget of the congregation ${ }^{30}$.

${ }^{29}$ Cf. D. Dawson, Allegorical Readers and Cultural Revision in Ancient Alexandria, Berkeley 1992, 81.

${ }^{30}$ Cf. Safrai, Education and the Study of Torah, p. 956-7. He also reports that even though the teachers were paid for their instructions it was rather represented as a reimbursement for the time they could spend while earning their bread elsewhere or a salary for teaching punctuation and accents which are not part of the Torah. Teaching of the Torah was deemed to be a noble enterprise that commanded it to be done for free and prohibited the payment for it; cf. also Mt 10:8; Derek Eretz Zuta 4. 
Introduction to letters and access to texts was seen in late antique Egypt as access to a higher social status, which customarily was guarded by the GrecoRoman élite that exercised and promoted education in its own exclusive circles and eagerly ensured that outsiders stayed out of it. Ptolemaic Alexandria allowed for a range of social classes, some of which enjoyed certain privileges without necessarily being full citizens, demesmen ${ }^{31}$. Despite the Roman prohibitions of intermarriage, the mingling of ethnic groups was not a lacking phenomenon but was common especially in Egypt. Not only in the province, but even in a city with a population of nearly half a million like Alexandria, local teachers could not fully satisfy the demand for instruction in letters and professions. Ewa Wipszycka emphasized that Christian communities in Alexandria from the very beginning of its existence participated in making elementary education available to its members as well as to newcomers, mainly Greeks but also people of other ethnic groups. The latter included those who traveled to Alexandria and Egypt from all over the world to gain quick success, economic stability, social reputation, and a status that were unavailable to them elsewhere ${ }^{32}$. Many outsiders regarded Egypt as an exotic paradise where things were happening dynamically and opportunities were abundant. And they did have good reason to think $\mathrm{so}^{33}$. Growing economic prosperity boosted by the Ptolemies and reformed by the Romans and its strategic location fitly chosen by Macedonians in the third century BCE led Alexandria to be praised as: „Seat of the immortal gods, august and wealthy, foundation of Alexandria! The gentle climate and fertile soil of Egypt provide you with all good things, happy land! There is abundant grain, infinity flax; from your harbors sail ships with rolls of papyrus and brilliant glass" ${ }^{\prime 34}$.

Thus, those who lived in Alexandria and those who came to it later were able to integrate into a society, which shared an unparalleled diversity but also a common interest and goal. Besides the economic enticement and relative

${ }^{31}$ Cf. P. M. Fraser, Ptolemaic Alexandria, vol. 1: Text, Oxford 1972, 38-92, esp. p. 49.

${ }^{32}$ Cf. E. Wipszycka, Le degré d'alphabétisation en Égypte byzantine, REAug 30 (1984) 279-296; see R.L. Wilken, Alexandria: A School for Training Virtue, in: Schools of Thought in the Christian Tradition, ed. by P. Henry, Philadelphia 1984, 15-30. For a larger perspective of the discussed issue in Early Christianity, cf. G.J.M. Bartelink, ,Illiteratus” in Early Christian and Medieval Texts: Church and Illiteracy, in: Jerusalem, Alexandria, Rome. Studies in Ancient Cultural Interaction in Honour of Antonius Hilhorst, ed. by F.G. Martínes - G.P. Luttikhuizen, Supplements to the „Journal for the Study of Judaism” 82, Leiden - Boston 2003, 1-12.

${ }^{33}$ Cf. A.K. Bowman, Egypt after the Pharaohs: 332 BC-AD 642. From Alexander to the Arab Conquest, London 1986, 56ff; N. Lewis, Greeks in Ptolemaic Egypt: Case Studies in the Social History of the Hellenistic World, Oxford 1986, 10; both authors quoted by M.J. Brown, The Lord's Prayer Through North African Eyes. A Window into Early Christianity, New York 2004, 76-77; see also the entire section on Alexandria in: Brown, The Lord's Prayer, p. 74-120 (Chapter 3: The Tableau of Roman Alexandria).

${ }^{34}$ Cited in: F.W. Walbank, The Hellenistic World, Fontana History of the Ancient World, Brighton 1981, 114. 
religious tolerance, educational institutions, either Greek, Roman, or Jewish, were perhaps the most adapting and integrating vehicles through which the city reached its importance and fame in antiquity. Christian groups, regardless of their Apocalyptic, Judeo-Christian, Christian-Gnostic, or Catholic congregational ,denomination”, consisted of educated rabbis like Apollo or later of such teachers as Valentinus, Clement and Origen. Even if they were of Jewish descent, these teachers were unburdened with the necessity to teach in Hebrew. After Paul's missionary allowance to accept uncircumcised, Judeo-Christian churches and schools were open to accept non-Jews into their circles. Finally, and not less importantly, they had a stability of salary which allowed them to serve their congregations for a fixed compensation. Such highly educated teachers like Clement made the élite luxury of Greco-Roman paideia accessible to essentially everyone who wanted it.

As B.A. Pearson most recently pointed out, the traditional perception that early Christian Alexandrian teachers and their audience were the people of education and means who enjoyed a comfortable life as part of Egyptian middle class is true only to a limited degree. There is more evidence to support the view that the new membership of the Christian congregations came from all social strata and ages, both literate and of means, as well as illiterate and of little or no means. Christian groups, supported by everyone who belonged to it, afforded to keep their doors open to everyone ${ }^{35}$. The late antique structure of the family exercised an important social role in the dynamic growth of the second century Alexandria. This is why Peter R.L. Brown dubs early church both in Rome and Alexandria ,a loose confederation of believing households" ${ }^{36}$, thereby making participation in the synagogue/church life open not only to the adults but also to their children, who, as was well established in the Second Temple Jewish custom both in Palestine and in Diaspora, had to מיב (דיב דפס), the House of Book, and from the age of twelve or thirteen and on in the Beth Talmud (חיב דמלח), the House of Learning ${ }^{37}$. For those who wanted to

${ }^{35}$ Cf. Pearson, Gnosticism and Christianity, p. 21, made this statement against A. Jakab (Ecclesia alexandrina, pp. 175-214), who was of the opinion that Clement's audience must have come from the middle class.

${ }^{36}$ P.R.L. Brown, The Body and Society. Men, Women, and Sexual Renunciation in Early Christianity, Lectures on the History of Religions N.S. 13, New York 1988, 135. P.R.L. Brown rightly reminds us that we should not forget that, „for Clement, Christ's words «when two or three are gathered in my name» meant father, mother, and a child praying in a Christian home".

${ }^{37}$ Shemuel Safrai (Education and the Study of Torah, p. 955-957) describes Beth Sepher (חיב דפס), the House of Book, which was the study of letters and reading on megillah (a small scroll) by Sofer, the teacher of letters, who taught children of age six for about five years (usually from 9 a.m. or early in the morning until the noon) and Beth Talmud (חיב דמלח), the House of Learning, which was the study of Mishnah or oral Law by Mashneh, the teacher of oral Law, who taught children of the age twelve or thirteen during different lengths of years (five, six or even longer) with two 
continue their studies, they could do so in the higher scribal rabbinical schools that were not lacking in Alexandria prior to Trajan's pogrom. This Jewish educational program corresponded to the Greek and Roman tiers of education and distinguished the elementary, secondary, and higher levels of paideia. In other words, sofer became the pedagogue, while rabbi and mashneh became the didaskalos and presbyteros (a new title which was first hardly distinguishable from didaskalos but with time acquired more of a clerical flavor).

In the course of the church's progression into Greco-Roman milieu, by the end of the third century most of the teacher's functions shifted to institutionalized ones. This shift took place from the privately run congregations and/or congregational schools. These schools had been subjugated by ecclesiastical officials, presbyters and bishops, who centralized and administered the catechetical institutions and incorporated them into the larger communal infrastructure. In fact, towards the fourth century and afterwards, the institutionalization of Christianity resulted in a widely avowed exclusivity of teaching granted only to ecclesiastically approved officeholders, which by some scholars today is seen as the shift back from the „educational” revolution commenced by early Christian teachers ${ }^{38}$.

Alexandria is no exception in this regard. Egyptian Christianity represented a multifaceted tradition formed by a number of coexisting schools, both or-

sessions, one in the morning and another in the afternoon. Writing was reserved as a professional skill. Curiously, a bachelor could not be a teacher, because the customarily mothers brought children to school. „In the social hierarchy the teachers come last, the order being: sages, the «leaders of the generation», the heads of synagogues and finally the teachers, though many sources also count the teachers among the spiritual elite of the society". For Egyptian adaptation of Jewish synagogue and school, cf. J.G. Griffiths, Egypt and the Rise of the Synagogue, JTS 38 (1987) 1-15; A. Kasher, Synagogues as „Houses of Prayer" and „Holy Places” in the Jewish Communities of Hellenisitc and Roman Egypt, in: Synagogues in Antiquity, ed. by A. Kasher - A. Oppenheimer - U. Rapport, Jerusalem 1987, 119-132 (in Hebrew), transl. into English by N.H. Reisner in: Ancient Synagogues. Historical Analysis and Archeological Discovery, ed. by D. Urman - P.V.M. Flesher, vol. 1, Studia Post-Biblica 47/1, Leiden 1995, 203-220. On the use of the Greek educational model for the formation of Christian catechesis, cf. N. Widok, Inkulturation bei Klemens von Alexandrien, StPatr 26 (1993) 559-568; F. Drączkowski, Dowartościowanie kultury intelektualnej przez Klemensa Alexandryjskiego jako rezultat polemiki antyheretyckiej, SPelp 5 (1975) 189-196. On the other hand, some argued that Christian education for children in the early church was transmitted only at home, cf. A.J. Clark, Child and School in the Early Church, „Comparative Education Review” 66 (1968) 468-479; G. Ruhbach, Bildung in der Alter Kirche, in: Kirchengeschichte als Missionsgeschichte, Bd. 1: Die alte Kirche, hrsg. von H.G. Frohnes - U.W. Knorr, München 1974, 293-310; Neymeyr, Die christlichen Lehrer im zweiten Jahrhundert, p. 1.

${ }^{38}$ Cf. G. Bardy, Les écoles romaines au second siècle, RHE 28 (1932) 501-32; idem, L'Église et l'enseignement pendant les trois premiers siècles, RevSR 12 (1932) 1-28; idem, Aux origines de l'école d'Alexandrie, RSR 27 (1937) 65-90; idem, Pour l'histoire de l'école d'Alexandrie, „Vivre et Penser" 2 (1942) [= RB 51 (1942)] 80-109; R. Gryson, The Authority of the Teacher in the Ancient and Medieval Church, JES19 (1982) 176-182; J.K. Coyle, The Exercise of Teaching in the Postapostolic Church, ET 15 (1984) 23-43. 
thodox and heterodox. However, as soon as the work of Irenaeus arrived in Alexandria some twenty years or earlier after it was originally produced, the more stringently defined Christianity was raising its voice to draw a clearer line between ,orthodoxy” and ,heresy"39. Jerome (c. 347-419) informs that before the episcopacy of Dionysius (248-264/265), the presbyters of Alexandria chose one among themselves to be bishop, and he acted like one without consecration ${ }^{40}$. The clash between Demetrius and Origen, which resulted in Origen leaving the city of Alexandria, is well recorded, as C.W. Griggs reconstructs the circumstances. Since Origen was ordained and consecrated by bishops of Palestine and was winning international reputation, he became a rival for Demetrius and was able to possibly change the latter in episcopal service ${ }^{41}$. After Origen was forced to leave Alexandria, his disciple Heraclas (d. 248) became the head of the Alexandrian school, and he also became the next bishop of Alexandria after Demetrius' death in 233 marking a complete takeover of the ecclesial supervision of the formerly freelance catechetical school ${ }^{42}$.

Table 1. Ancient Tiers of Education ${ }^{43}$

\begin{tabular}{|l|l|l|l|}
\hline & Greek $^{44}$ & Roman & Jewish \\
\hline Elementary & $\begin{array}{l}\text { Three schools (grammar, music, and } \\
\text { physical education) }\end{array}$ & Ludus/Ludi & Beth ha-Sepher \\
\hline Secondary & Advanced grammatical studies & Schola & $\begin{array}{l}\text { Beth Talmud/Beth } \\
\text { ha-Midrash }\end{array}$ \\
\hline $\begin{array}{l}\text { Higher } \\
\text { Education }\end{array}$ & $\begin{array}{l}\text { Philosophy, rhetoric, or law/ } \\
\text { medicine }\end{array}$ & $\begin{array}{l}\text { Rhetorical } \\
\text { schools }\end{array}$ & $\begin{array}{l}\text { Scribal/rabbinical } \\
\text { schools }\end{array}$ \\
\hline
\end{tabular}

${ }^{39}$ Cf. Griggs, Early Egyptian Christianity, p. 34; see also L.G. Patterson, The Divine Became Human: Irenaean Themes in Clement of Alexandria, StPatr 31 (1997) 497-516.

${ }^{40}$ Cf. Hieronymus, Epistula 146, 1, 6, CSEL 56, 310, 8-10: „Nam et Alexandriae a Marco euangelista usque ad Heraclam et Dionysium episcopos presbyteri semper unum de se electum et in excelsiori gradu conlocatum episcopum nominabant".

${ }^{41}$ Cf. Griggs, Early Egyptian Christianity, p. 62. C.W. Griggs refers to Eusebius Caesariensis (HE VI 8, 5, SCh 41, 96) and to the study of M. Hornschuh (Das Leben des Origenes und die Enstehung der alexandrinischen Schule, ZKG 71:1960, 210-212).

${ }^{42}$ Cf. D. Brakke, The East, II: Egypt and Palestine, in: The Oxford Handbook of Early Christian Studies, ed. by S.A. Harvey - D.C. Hunter, Oxford 2008, 348-350.

${ }^{43}$ The table with my minor additions is taken from J.R. Estep Jr., Philosophers, Scribes, Rhetors ... and Paul? The Educational Background of the New Testament, „Christian Education Journal” 2 (2005) 33 (Table 1).

${ }^{44}$ Greek education in the classical period had only two tiers, but later developed a third during the Hellenistic period, which was then mimicked by the Romans. 


\section{TRANSFORMACJA EDUKACJI JAKO WARUNEK USTANOWIENIA STOLICY BISKUPIEJ W ALEKSANDRII W II I III WIEKU}

\section{(Streszczenie)}

Starożytna Aleksandria to kosmopolityczna metropolia, swoiste skrzyżowanie kultur i religii Cesarstwa Rzymskiego oraz uznane centrum naukowe świata antycznego. Tę pozycję miasto zawdzięczało Ptolemeuszom. Owa wyrosła w okresie hellenistycznym stolica wschodniego basenu Morzy Śródziemnego stała się w II i III wieku po Chr. miejscem spotkania trzech najwyżniejszych nurtów religijnospołecznych epoki: hellenizmu, judaizmu i chrystianizmu. Chrześcijanie aleksandryjscy, aby uniezależnić się od silnych wpływów kwitnącego w mieście życia intelektualnego hellenizmu i judaizmu, zostali niejako zmuszeni do stworzenia własnego środowiska intelektualnego, którego podstawą stał się autonomiczny system edukacji. Przy jego tworzeniu szczególne miejsce przypadło judaizmowi. Funkcja nauczyciela, rabbi, niezwykle ważna w judaizmie, została przejęta przez młode chrześcijaństwo aleksandryjskie i zmodyfikowana w duchu grecko-rzymskiej paidei. W konsekwencji powstał swego rodzaju nowy typ chrześcijańskiego nauczyciela-pedagoga. To właśnie hellenistyczny model edukacji, paideia, dopomógł prawdopodobnie chrystianizmowi uniezależnić się od modelu edukacji proponowanej przez judaizm. Było to również ściśle związane z napływem prozelitów helleńskich do młodej wspólnoty aleksandryjskich wyznawców Chrystusa. W konsekwecji nastąpiło w tamtejszym chrześcijaństwie przejście od modelu edukacji judaistycznej do modelu autonomicznego, w którym silna pozycja przypadła ,pedagogice” grecko-rzymskiej. Transfomacja ta miała m.in. na celu podniesienie rangi szkolnictwa chrześcijańskiego i uczynienia go atrakcyjnym dla helleńskich prozelitów. Klasyczna paideia pozwoliła chrześcijanom wejść do grona wykształconej społeczność metropolii nad Nilem, a biskupom Aleksandrii - następcom św. Marka - odgrywać ważną rolę w życiu miasta. Owo skrzyżowanie wpływów judaizmu i hellenizmu widać dobrze w twórczości Klemensa Aleksandryjskiego i Orygenesa, których dokonania wzmacniały (mimo wszystko) pozycję lokalnego biskupa. Drugim dowodem krzyżowania się rzeczonych wpływów jest powstanie gnozy chrześcijańskiej. W ten sposób Aleksandria stała się miejscem koegzystencji ortodoksji i heterodoksji w łonie chrystianizmu. Ów system edukacji chrześcijańskiej oparty na gruncie dziedzictwa wielokulturowej metropolii znajdował się zatem niejako z konieczności pod kontrolą hierarchii kościelnej. Tak stworzono podwaliny pod przyszłą teologiczną hegemonię starożytnego patriarchatu aleksandryjskiego. 